\title{
BILATERAL SUDDEN MIXED HEARING LOSS: CASE STUDY
}

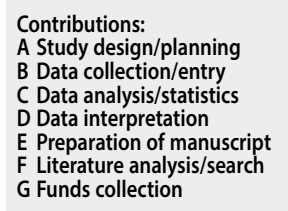

G Funds collection

\section{Edyta Piłka ${ }^{1, A-F}$, Małgorzata Pastucha ${ }^{1, B-F}$, W. Wiktor Jędrzejczak ${ }^{1, A, D-E}$, Ewa Orkan-Łęcka ${ }^{2, B, D}$, Elżbieta Włodarczyk ${ }^{3, B, D}, K_{\text {rzysztof Kochanek }}^{\text {4,A,D-E }}$}

\author{
${ }^{1}$ Department of Experimental Audiology, Institute of Physiology and \\ Pathology of Hearing, Poland \\ ${ }^{2}$ Otolaryngology Clinic, Central Clinical Hospital of the MSWiA, Poland \\ ${ }^{3}$ Rehabilitation Clinic, Institute of Physiology and Pathology of Hearing, Poland \\ ${ }^{4}$ Scientific Secretary, Institute of Physiology and Pathology of Hearing, Poland
}

Corresponding author: Edyta Piłka; Department of Experimental Audiology, Institute of Physiology and Pathology of Hearing, Mochnackiego 10, 02-042, Warsaw, Poland; email: e.pilka@ifps.org.pl; Phone: +48 223560359

\begin{abstract}
Background: This study presents a case of a patient with sudden hearing loss of a mixed type in both ears.

Case report: A 45-year-old man came to our center for consultation because he had had no improvement in hearing after therapy in another clinic. In our clinic the patient was treated for 2 weeks. During each of his visits to our center, a battery of tests assessing the hearing organ were performed: pure-tone audiometry, impedance audiometry, and absorbance measurement. Decisions concerning the treatments to be applied were agreed between both centers managing the patient. In consecutive visits improvement of hearing was observed.

Conclusions: As test results showed, treatments with a wider spectrum of action, such as anti-inflammatory and immunosuppressant drugs, inhalations with an AMSA inhaler, and hyperbaric oxygen therapy restored the patient's hearing and eliminated the concurrent ailments he reported during the first visit.
\end{abstract}

Key words: sudden deafness $\bullet$ mixed hearing loss $\bullet$ absorbance $\bullet$ sensorineural hearing loss

\section{OBUSTRONNY NAGŁY NIEDOSŁUCH O CHARAKTERZE MIESZANYM}

\section{- STUDIUM PRZYPADKU}

\section{Streszczenie}

Cel: Celem pracy jest przedstawienie przypadku pacjenta z obustronną nagłą utratą słuchu typu mieszanego.

Studium przypadku: 45-letni mężczyzna zgłosił się do naszej placówki w celu konsultacji, ponieważ po podjęciu terapii w innym ośrodku nie nastąpiła spodziewana poprawa słyszenia. W naszej klinice pacjent był leczony przez dwa tygodnie. Podczas każdej wizyty w naszym ośrodku wykonywany był zestaw testów oceniających narząd słuchu: audiometria tonalna, audiometria impedancyjna oraz pomiar absorbancji. Decyzje dotyczące zastosowanych metod leczenia były konsultowane między oboma ośrodkami leczącymi pacjenta. Na kolejnych wizytach zaobserwowano poprawę słuchu.

Wnioski: Jak wykazały wyniki badań, wdrożenie zabiegów o szerszym spektrum działania, takich jak leki przeciwzapalne i immunosupresyjne, inhalacje inhalatorem AMSA, tlenoterapia hiperbaryczna, doprowadziło do przywrócenia słuchu i eliminacji współistniejących dolegliwości, o których mówił podczas pierwszej wizyty pacjent.

Słowa kluczowe: nagła głuchota $\bullet$ niedosłuch mieszany $\bullet$ absorbancja $\bullet$ niedosłuch odbiorczy

\section{Introduction}

According to the definition of the Polish Society of Audiology and Phoniatrics, 'sudden hearing loss' is the sudden deterioration of hearing of the sensorineural type. The hearing loss usually has no identified cause, develops for no more than 3 days, occurs in one or (more seldom) in both ears, encompasses at least three adjacent frequencies, and is equal, or higher than $30 \mathrm{~dB} H \mathrm{HL}[1,2]$. Clinical diagnostics, time of commencement, and method of treatment should be matched individually to the ailments reported by the patient $[3,4]$. Most often, sudden deafness relates to problems inside the cochlea, such as idiopathic rupture of the basilar or vestibular (Reissner's) membrane, impaired blood flow to the organ of hearing, or a viral cochlear infection $[5,6]$. Less often, sudden deafness involves a non-cochlear sensorineural hearing impairment related to a CN VIII tumor or autoimmune disease $[4,5]$.

Research shows that one of the causes of hearing loss may be viral infection, which not only directly damages structures of the inner ear (sensorineural hearing loss), but also causes inflammation, leading to conductive or mixed losses [7]. In the literature, the most frequently reported cases are patients with sensorineural hearing loss in addition to hearing loss due to chronic inflammation of the middle ear [8-10]. Unfortunately, despite surgical intervention related to sound conduction, the sensorineural component of hearing loss can remain, and in some cases deteriorate over time. Song et al. (2012) offer some guidance in cases of unilateral sudden sensorineural deafness 
Table 1. Schedule of visits, patient's ailments, treatment plan, and tests performed

Visit 0
Additional information: auditory tubes periodically blocked before the episode of hearing deterioration
In otoscopy - fluid in the middle ear
Treatment: antibiotics, anti-inflammatory drugs, immunosuppressants, pain medication, topical decongestants
Tests: PTA
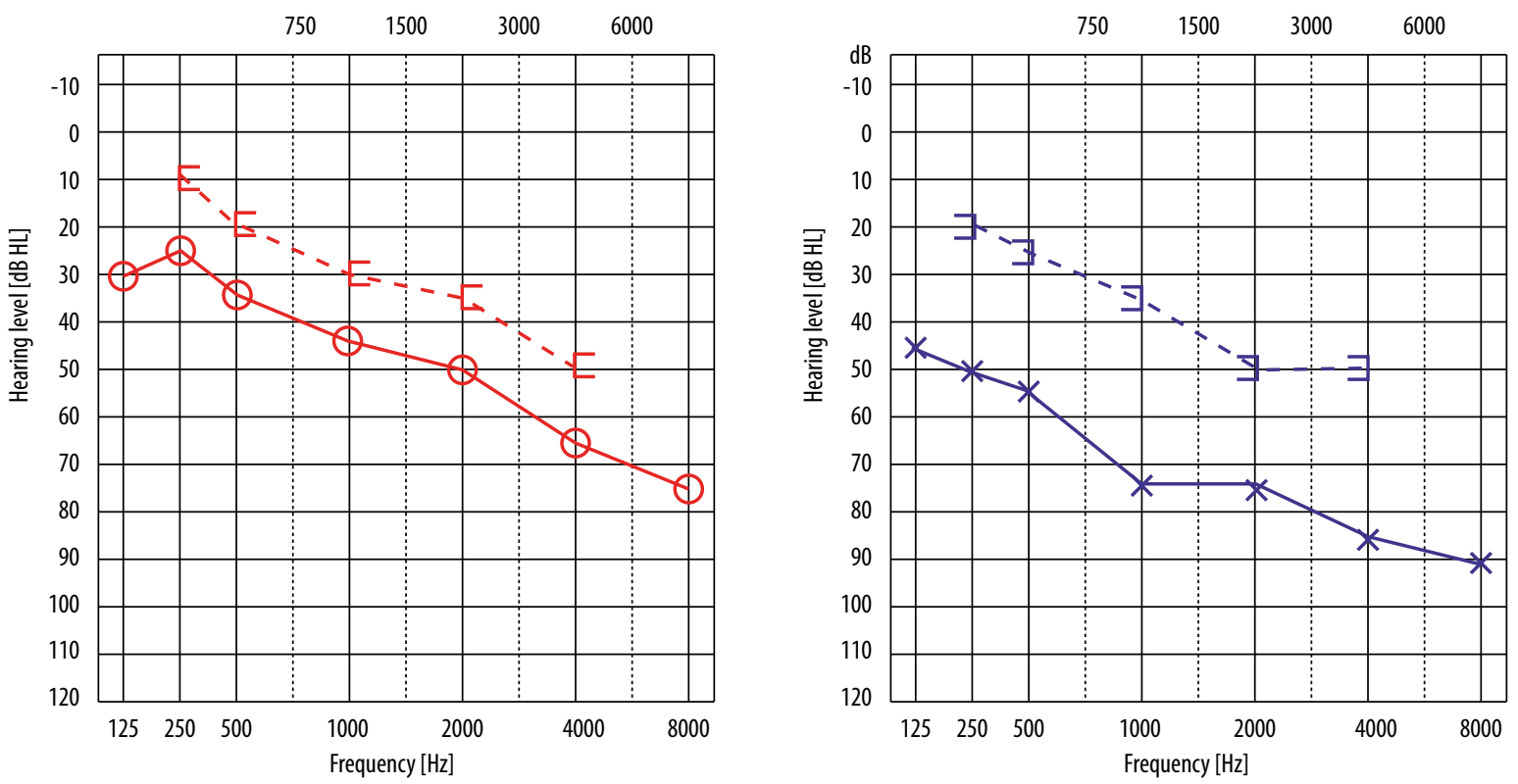

Figure 1. Patient's audiogram at visit 0 . Left: hearing threshold for the right ear (red); right: hearing threshold for the left ear (blue)

caused by an episode of acute otitis media [11]. The study highlights the dual nature of treatment aimed at eliminating inflammation through drainage and antibiotic therapy, as well as receiving steroids.

This study presents the case of a patient with bilateral sudden hearing loss of a mixed type.

\section{Material and method}

A 45-year-old man reported to our center for consultation after treatment for bilateral sudden hearing loss. Table 1 presents the schedule of visits, the patient's ailments, management description, and tests performed in the course of treatment. Visit 0 took place in the first center, where the patient went when his hearing problem first occurred, and visits 1 through 6 took place in our clinic. Due to the reported problems with hearing impairment and the accompanying ailments, during visit 0 the patient was given an antibiotic, anti-inflammatory, immunosuppressive, and analgesic drugs, together with a local nasal decongestant. Then, during visit 1 , inhalations of the upper respiratory tract and hyperbaric oxygen treatment were additionally introduced. Pure tone audiometry (PTA) was performed using a Madsen Astera (GN Otometrics) clinical audiometer. Hearing thresholds for air conduction were measured from 0.125 to $8 \mathrm{kHz}$ (using Sennheiser HDA200 headphones) and for bone conduction from 0.25 to $4 \mathrm{kHz}$ (B-71 transducer). We assumed that an air and bone conduction threshold below $20 \mathrm{~dB}$ represented normal hearing, as per the BIAP scale [12]. Tympanometry (IA) and energy absorbance (AM) were measured using the Titan device (Interacoustics). Standard tympanograms were measured using a test tone of $226 \mathrm{~Hz}$. Interpretation of the tympanometry results was based on the analysis of static admittance [13] and assessment of the tympanogram shape according to the types proposed by Jerger and Linden (A, As, Ad, B, C, D, and E) [14,15]. Absorbance was 

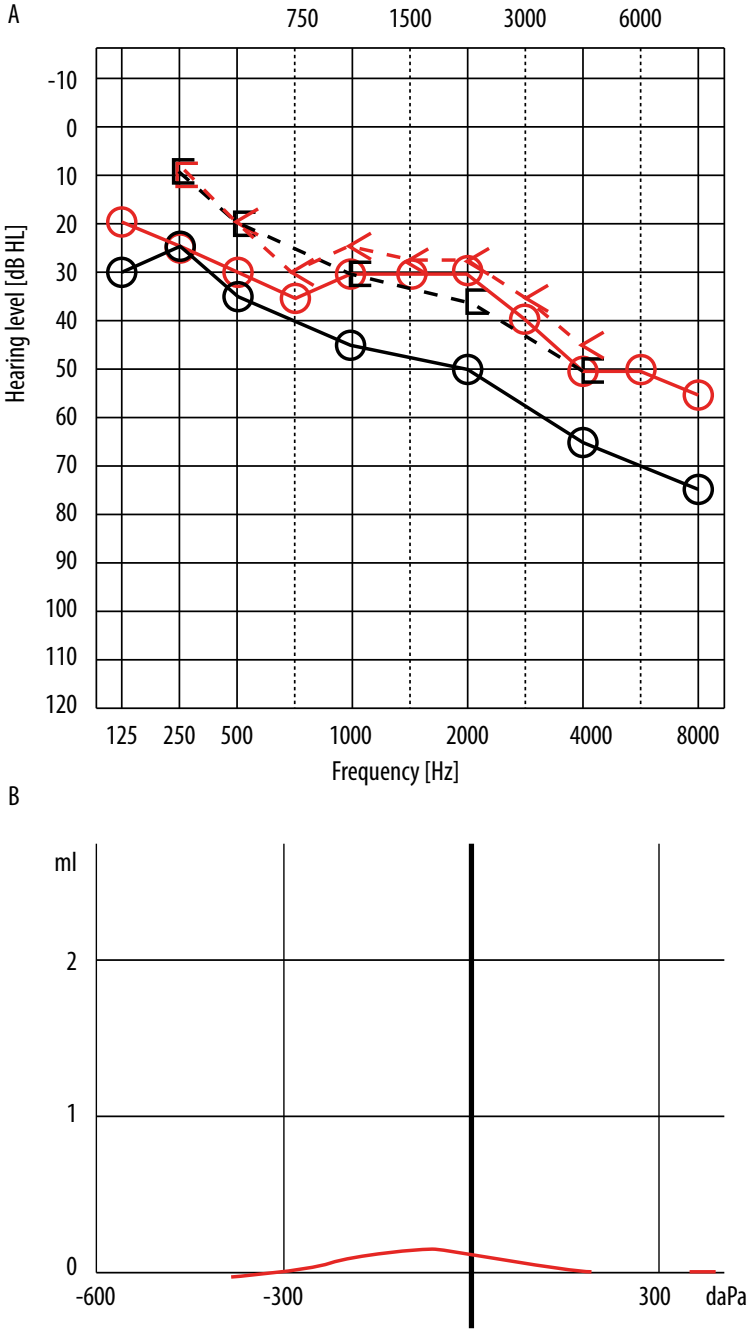

$\mathrm{ECV}: 0,83 \mathrm{ml}$

SC: $-0,12 \mathrm{ml}$

MEP: $-75 \mathrm{daPa}$
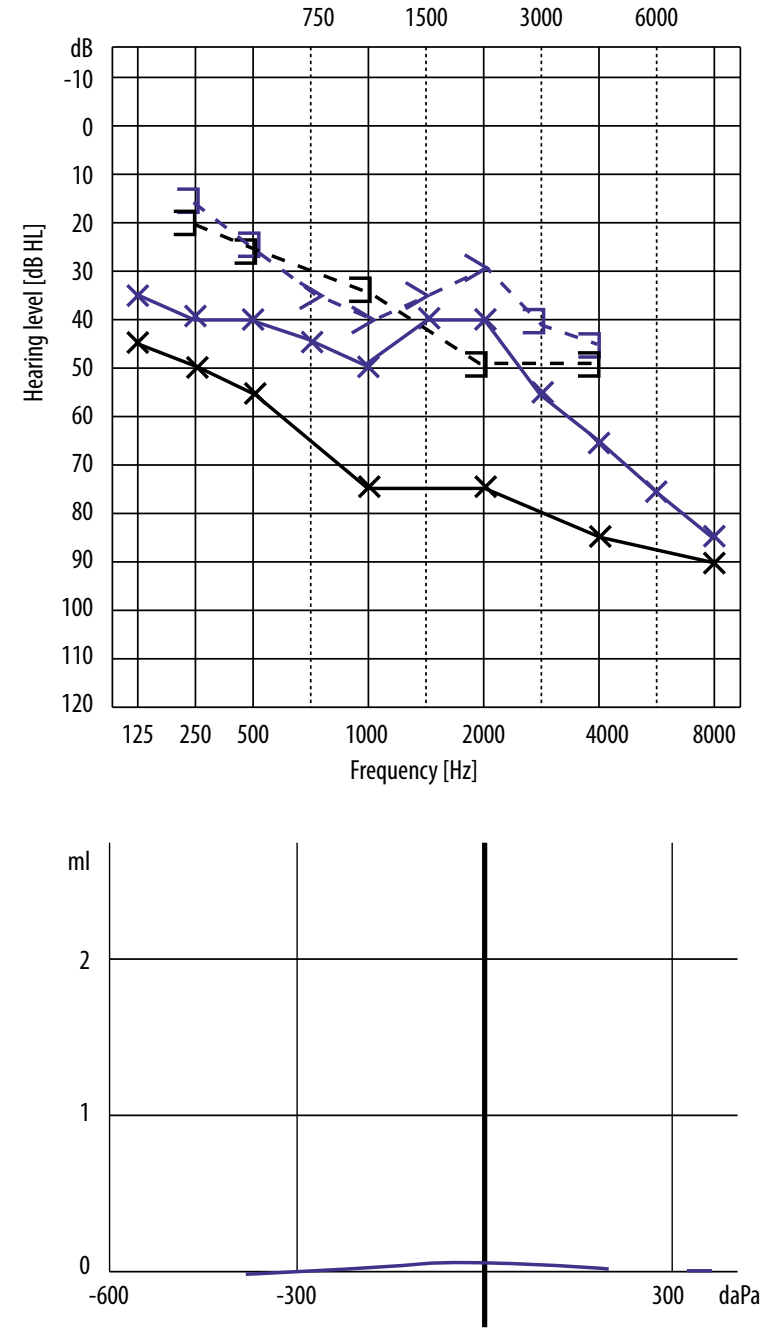

$\mathrm{ECV}: 0,85 \mathrm{ml}$

Figure 2. Hearing tests at visit 1. A: Audiograms for the right ear (red) and left ear (blue). Black lines are results for visit 0. $\mathrm{B}$ : Corresponding tympanograms

measured as a function of variable pressure in the external ear canal in the range +200 to $-400 \mathrm{daPa}$ and over 226 to $8000 \mathrm{~Hz}$. Results were presented as a function of absorbance in relation to the tympanometric peak pressure (TPP) [16-19].

Additionally, as a gold standard, standard impedance audiometry was done using a Madsen Zodiac 901 clinical tympanometer (GN Otometrics). Tympanograms were registered with a standard $226 \mathrm{~Hz}$ test tone. A stapedius reflex test was performed using ipsilateral and contralateral stimulation using pure tones of $0.5-4 \mathrm{kHz}$ and 75 and $120 \mathrm{~dB}$ SPL.

Treatment decisions were developed in consultation between both centers managing this patient.

\section{Case presentation}

Figure 1 presents the results of pure-tone audiometry performed at visit 0 . It shows a mixed-type hearing loss: that is, the air-bone gap was preserved, but the bone conduction threshold from $1 \mathrm{kHz}$ is outside the hearing norm defined by BIAP. The hearing threshold plot showed a moderate hearing loss of 1st degree in the right ear and severe hearing loss of 1st degree in the left. Otoscopy at that time confirmed the presence of fluid in both middle ears.

Consultation in our center arose because the patient did not observe any notable improvement in their hearing despite lessening of their vertigo and catarrh. Moreover, he still felt 'fullness' in the ears, particularly on the left. In his medical history, there had been episodes of auditory tube blockage, even before the onset of the sudden hearing loss. The cause of the blockages is unknown.

\section{Results}

Figure 2 presents pure tone audiometry (A) and tympanometry (B) results obtained at visit 1 , after treatment prescribed at visit 0 (original hearing thresholds shown 


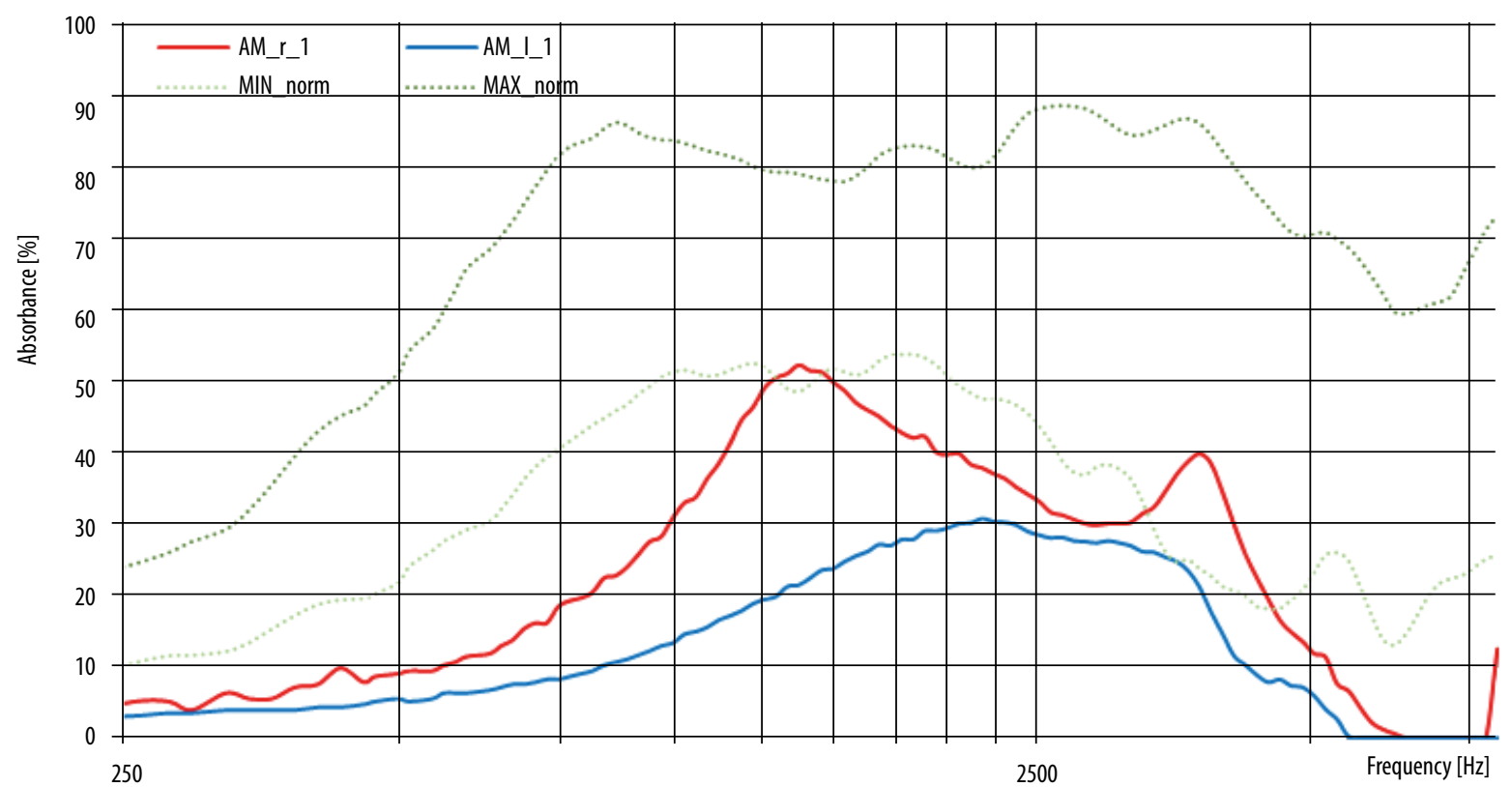

Figure 3. Absorbance measurement (AM) at visit 1 (red: right ear; blue: left ear). Dotted lines: maximum and minimum of normal values

in black). The audiogram shows an improvement of hearing in both ears. In the right ear (red), the plot indicates a mild sensorineural hearing loss. In the left ear (blue), it shows a 1st-degree moderate hearing loss of the mixed type, with a large sensorineural component (airbone gap is preserved only at low frequencies). Tympanometry shows a slight improvement on the right side - a peak is seen, but the Titan measurement system did not mark out the static admittance (parameter below $0.15 \mathrm{~mL}$ ) and middle ear pressure. In Figure $2 \mathrm{~B}$, the parameters SC and MEP for the right ear are marked manually. Measurement with the Zodiac 901 showed admittance in the right ear to be $0.13 \mathrm{~mL}$, and the tympanic cavity pressure was $-195 \mathrm{daPa}$, which represents a type $\mathrm{C}$ tympanogram. Additionally, an ipsilateral stapedius reflex was registered on the right for frequencies from 0.5 to $2 \mathrm{kHz}$ and intensities of 105, 110, and $105 \mathrm{~dB}$. On the left side, both systems registered a type $\mathrm{B}$ tympanogram.

Figure 3 shows the absorbance plot for both ears. Rigidity of the middle ear system both on the right and left has a negative effect on the absorbance, resulting in a decrease in the tested frequency band. For the right ear (red), measurements show values within the normal range at $1.3-1.5 \mathrm{kHz}$ and at $3.4-4.5 \mathrm{kHz}$, but for the left ear only at $3.5 \mathrm{kHz}$.

Figure 4A presents pure tone audiometry results at visit 2 . After implementation of the wider-spectrum treatment (Table 1, treatment described in visit 1), a marked improvement of hearing is noticeable, not only in relation to the threshold plotted at visit 0 (black line) but also in relation to the threshold plotted at visit 1 (green lines). The results of tympanometry in Figure 4B also show improvement compared to Figure 2 - the tympanogram in the right ear is type As, and in the left ear a peak in the tympanogram is visible, although the Titan system could not measure all parameters. In Figure 4B, the parameters SC and MEP for the left ear are marked manually. Measurements obtained with the Zodiac 901 show static admittance in the left ear at $0.1 \mathrm{~mL}$, and the tympanogram can be classified as type As.

Figure 5 shows the absorbance measurement at visit 2 and compares it to the results obtained at visit 1 . The minimal increase of the middle ear admittance in the right ear has resulted in an increase in absorbance below $1.2 \mathrm{kHz}$, in the $2.4-3.2 \mathrm{kHz}$ band, and above $5.2 \mathrm{kHz}$. However, normal values still only appear for $3.5 \mathrm{kHz}$. In the left ear, the absorbance measured at the second visit has grown at higher frequencies compared to the first visit; normal values are obtained in the band $1.6-3.5 \mathrm{kHz}$.

The results obtained at subsequent visits were similar to the results presented in Figures 4 and 5, so a summary of measurements performed at the last visit (visit 6) is presented in Figure 6, where an improvement of all parameters is visible. The audiogram in Figure 6A shows a significant improvement of hearing in comparison to the threshold curves plotted at visit 0 (black line). Compared to the measurements plotted at visit 2 in Figure 4A, improvement of hearing by 10-14 dB at high frequencies can be seen. Hearing in the right ear is now within the BIAP norm, even though the hearing threshold drops to $35 \mathrm{~dB}$ at high frequencies. The hearing loss in the left ear is classified as mild, and an air-bone gap is seen from 0.25 to $0.75 \mathrm{kHz}$, indicating the appearance of a conductive component. Tympanometry results in Figure 6B show improvement, especially on the right, where a type A tympanogram is registered. On the left side, due to a decrease in static admittance, a type As tympanogram is obtained. The measurement performed with a standard impedance bridge shows that the tympanogram peak on the left is shifted towards negative pressure but with a similar level of static admittance, which suggests a type $C$ tympanogram. Nevertheless, compared to before, both ears show a significant improvement in tympanometric parameters. 

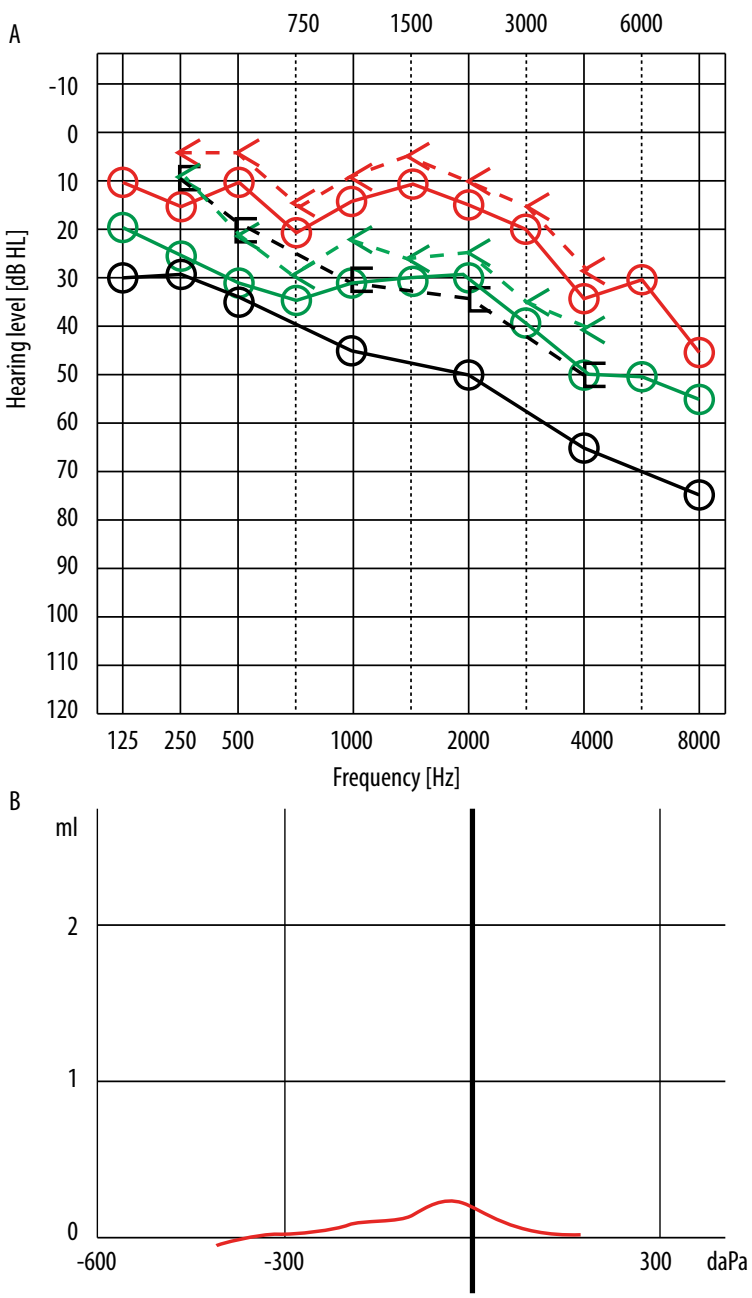

$\mathrm{ECV}: 0,83 \mathrm{ml}$

SC: $0,22 \mathrm{ml}$

MEP:-38 daPa
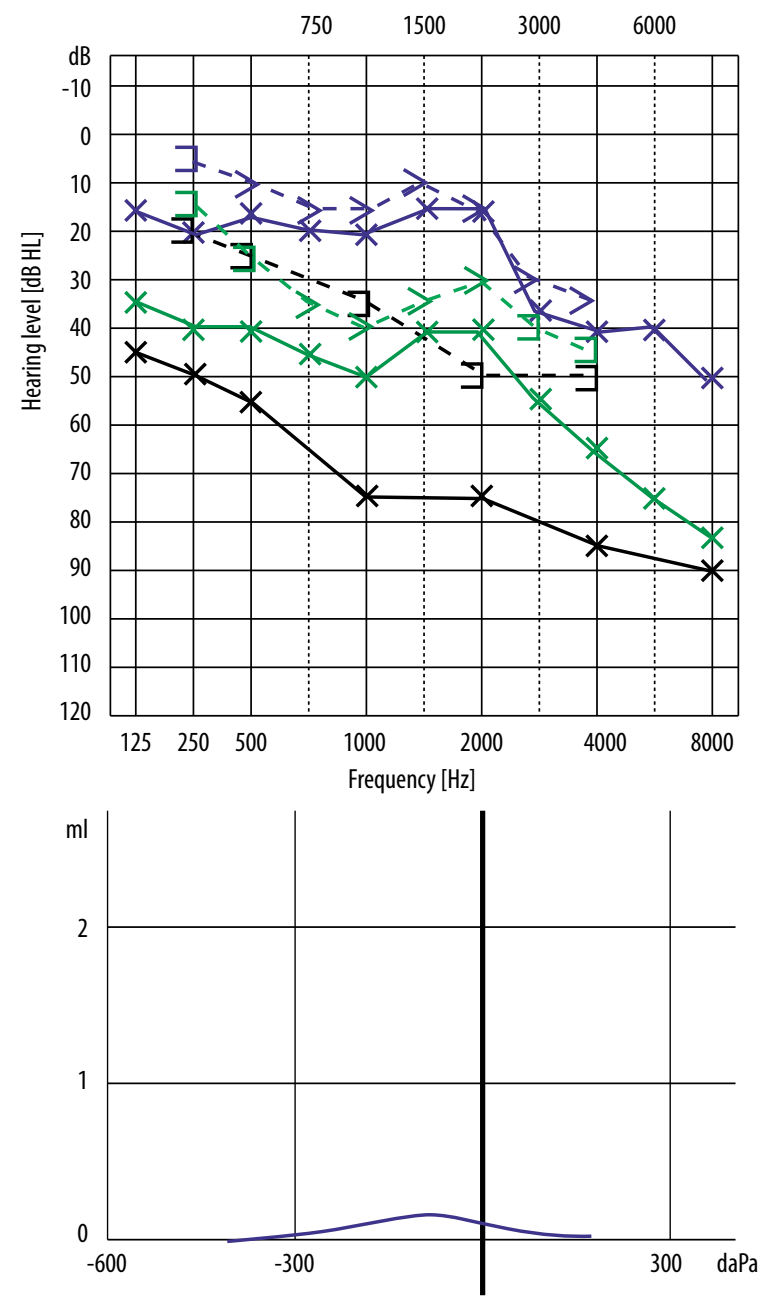

$\mathrm{ECV}: 0,92 \mathrm{ml}$ SC: $0,12 \mathrm{ml}$

Figure 4. Hearing tests at visit 2. A: Audiogram for the right ear in red (black, visit 0; green, visit 1); left ear is in blue and the other colours code for visits 0 and 1 . B: Corresponding tympanograms

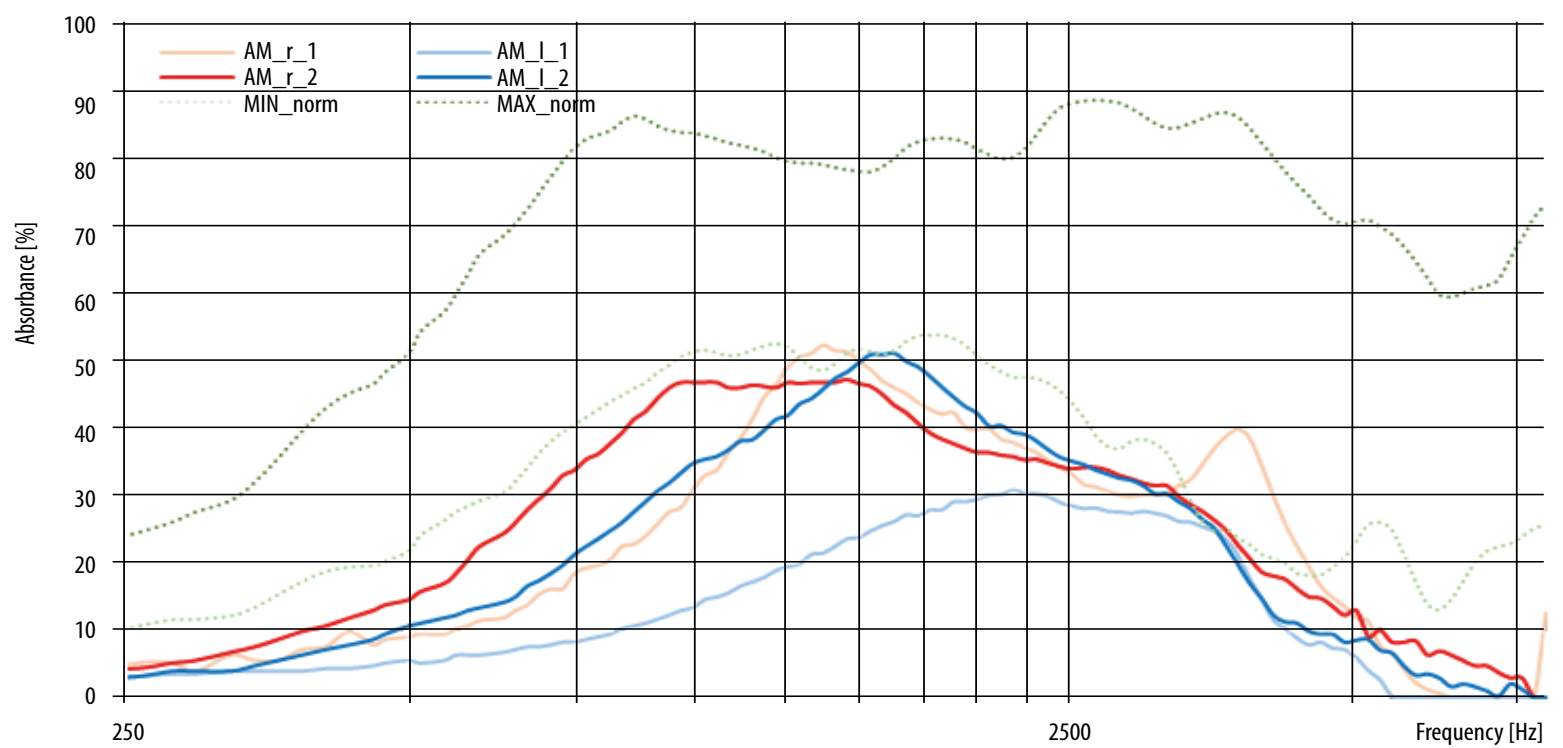

Figure 5. Absorbance measurement (AM), visit 2 (red, right ear; blue, left ear; lighter colors show results for visit 1) 

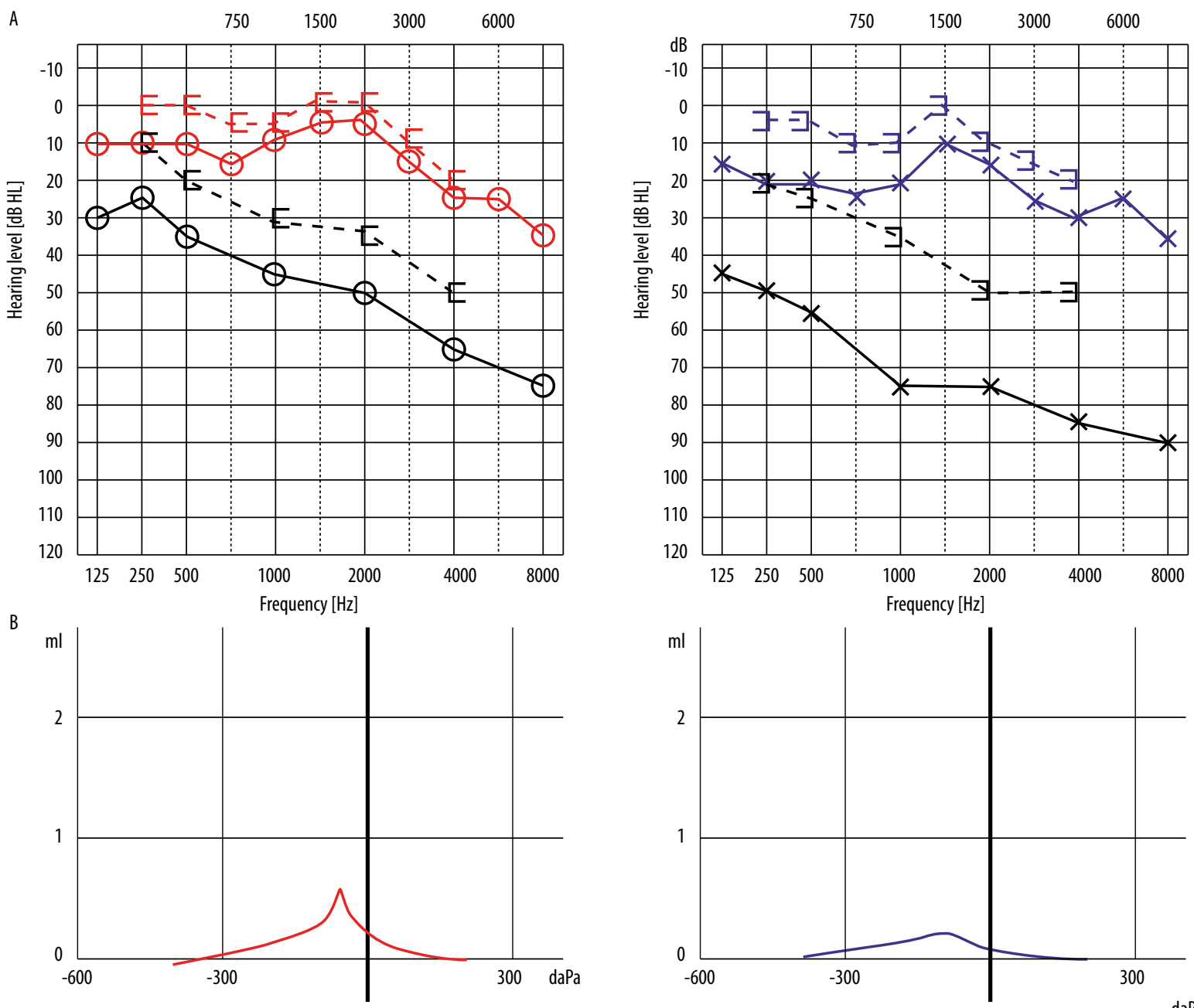

ECV: $0,95 \mathrm{ml}$

MEP: -57 daPa

SC: $0,58 \mathrm{ml}$

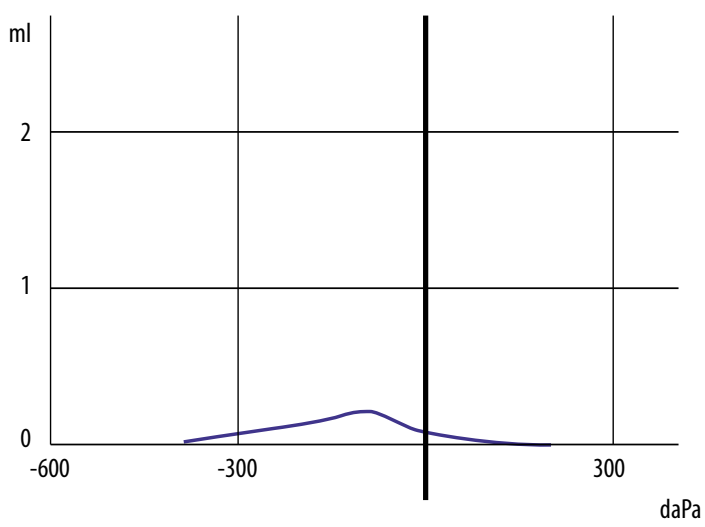

$\mathrm{ECV}: 0,83 \mathrm{ml}$

MEP: -94 daPa

SC: $0,20 \mathrm{ml}$

Figure 6. Hearing tests at the last visit (visit 6). A. Audiograms for the right ear (red) and left ear (blue). Black lines are results for visit 0 . B. Corresponding tympanograms

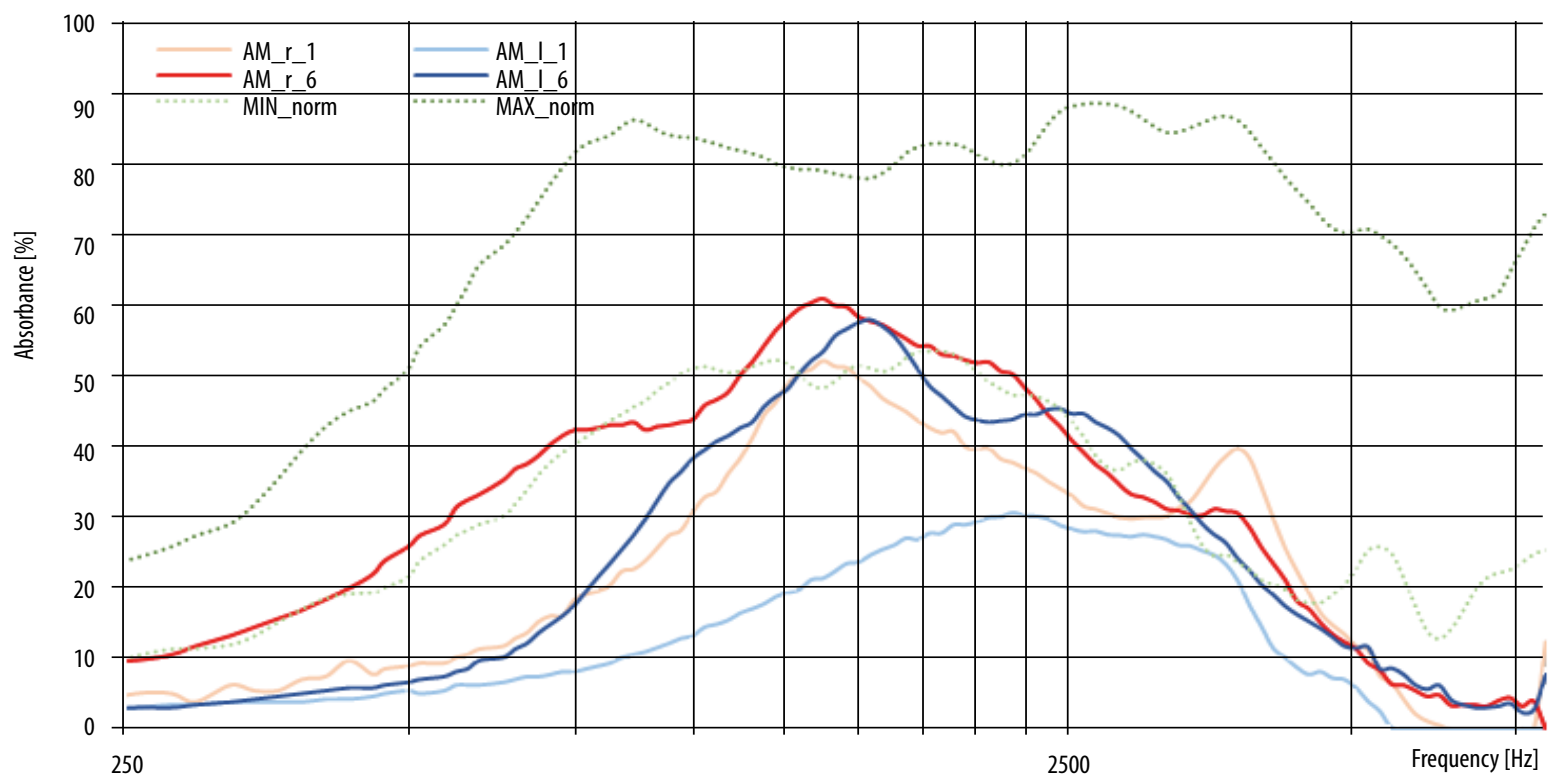

Figure 7. Absorbance measurement (AM) for visit 1 (light colour) and visit 6 (dark colour) 
Figure 7 shows the absorbance measurement performed at visit 6 . In the right ear (red), due to a significant increase in static admittance and a decrease in negative middle ear pressure, absorbance has grown over the entire frequency range and has achieved normal values (with the exception of $4.3-5.5 \mathrm{kHz}$ ). In the left ear, compared to the first measurement where the pressure parameters were not measurable, the absorbance has grown over the whole frequency range except for the lowest frequencies. Normal values are obtained only in the medium frequency range. As the figure shows, results in the left ear are much worse than in the right.

\section{Conclusions}

This study presents the case of a patient with a sudden bilateral hearing loss of the mixed type.

The pure tone audiometry results obtained during visit 1 show that the hearing thresholds have improved compared to the tests performed at visit 0 in another center. The average improvement of air conduction thresholds in the right ear were about 5,17 , and $18 \mathrm{~dB}$ for low, medium, and high frequencies, respectively, while in the left ear they were about 12,32 , and $14 \mathrm{~dB}$. The air-bone gap, previously present over the entire frequency range, remained only in the low frequencies.

As soon as one day after the introduction of additional treatment, improvement of the air conduction threshold was observed in the right ear, at low frequencies by about $18 \mathrm{~dB}$ and at medium and high frequencies by about $33 \mathrm{~dB}$. In the left ear, improvement was markedly greater - by about 35,58 , and $45 \mathrm{~dB}$, respectively. The air-bone gap was seen only at $0.25 \mathrm{kHz}$ in the left ear. This status was maintained in the subsequent days of treatment.
After one week of treatment, air conduction hearing at high frequencies had improved by about $10-15 \mathrm{~dB}$. Unfortunately, due to recurring problems with the patency of the auditory tube on the left side noted in the case history, the air-bone gap re-appeared between 0.25 and $0.75 \mathrm{kHz}$. Analysis of the impedance audiometry results showed a similar improvement of the tympanometry results, which in turn were reflected by the absorbance measurements, which approached normal values as the middle ear system became less rigid.

Similar hearing improvements were obtained by Song et al. [11], where treatment for unilateral inflammation of the middle ear and sudden sensorineural deafness was applied. In 6 out of their 8 examined patients, improved speech and tonal audiometry results were obtained. The authors noted that antibiotics should be administered first, followed by steroids. In the case of our patient, simultaneous treatment was applied, i.e. an antibiotic and anti-inflammatory drugs together with steroids were administered, and, after a few more days, oxygen hyperbaric treatment was added to the therapy.

Summarizing, treatment applied at visit 0 resulted in a decrease in the conductive component of the hearing threshold but did not have any significant effect on a sudden deterioration in hearing. Only treatment targeting the auditory tube patency and improvement of cochlear perfusion, combined with therapy used for a typical sudden sensorineural hearing loss, enabled restoration of hearing to a level comparable to that before the "sudden deafness" episode. It can also be concluded that the patient's vertigo was due to the presence of middle ear fluid and abnormal auditory nerve function, and not by injury to the labyrinth.

\section{References}

1. Śliwińska-Kowalska M, Narożny W, Sekula A, Pawlak-Osińska K, Morawski K, Kot J, Kantor I, Karaszewski B, Konopka W. Nagły niedosłuch czuciowo-nerwowy - stanowisko Polskiego Towarzystwa Audiologicznego i Foniatrycznego dotyczące zaleceń diagnostycznych i terapeutycznych. [Sudden sensorineural hearing loss - the position of the Polish Society of Audiology and Phoniatrics on diagnostics and therapy.] Otorynolaryg, 2015; 14(2): $65-73$.

2. Narożny W. Nagła głuchota - stan naglący nie tylko dla otolaryngologa [Sudden deafness - an emergency not only for the ENT] Forum Medycyny Rodzinnej, 2007; 1(1): 17-24.

3. Rogowski M. Nagła głuchota. [Sudden deafness.] In: Audiologia kliniczna [Clinical Audiology], ed. Śliwińska-Kowalska M. 2005 Mediton Oficyna Wydawnicza, Łódź. s.263-269.

4. Mort DJ, Bronstein AM. Sudden deafness. Curr Opin Neurol, 2006 Feb; 19(1): 1-3.

5. Szmeja Z, Sekula A. Nagła głuchota. [Sudden deafness.] In: Audiologia kliniczna. Zarys. [Clinical Audiology, Guidelines], ed. Pruszewicz A, Obrębowski A. Wydawnictwo Naukowe Uniwersytetu Medycznego im. Karola Marcinkowskiego, Poznań, 2010. s. $445-52$.

6. Chen X, Fu YY, Zhang TY. Role of viral infection in sudden hearing loss. J Int Med Res, 2019 Jul; 47(7): 2865-72.

7. Cohen BE, Durstenfeld A, Roehm PC. Viral causes of hearing loss: a review for hearing health professionals. Trends Hear, 2014 Jul 29; 18: 2331216514541361.
8. Hydén D, Akerlind B, Peebo M. Inner ear and facial nerve complications of acute otitis media with focus on bacteriology and virology. Acta Otolaryngol, 2006 May; 126(5): 460-6.

9. da Costa SS, Schmidt Rosito LP, Dornelles C. Sensorineural hearing loss in patients with chronic otitis media. Eur Arch Otorhinolaryngol, $2009 \mathrm{Feb}$; 266(2): 221-4.

10. Park JH, Park SJ, Kim YH, Park MH . Sensorineural hearing loss: a complication of acute otitis media in adults. Eur Arch Otorhinolaryngol, $2014 \mathrm{Jul}$; 271(7): 1879-84.

11. Song JE, Sapthavee A, Cager GR, Saadia-Redleaf MI. Pseudosudden deafness. Ann Otol Rhinol Laryngol, 2012 Feb; 121(2): 96-9.

12. http://www.biap.org/en/recommandations/recommendations /tc-02-classification/213-rec-02-1-en-audiometric-classification -of-hearing-impairments/file

13. Kochanek K, Śliwa L. Metody obiektywne badania słuchu. [The objective methods of hearing assessment.] In: Protetyka słuchu [Auditory Prosthetics], ed. Hojan E. Wydawnictwo Naukowe UAM, Poznań. 2014. s. 211-48.

14. Jerger J. Clinical experience with impedance audiometry. Arch Otolaryngol, 1970; 92: 311-24

15. Liden G, Harford E, Hallen O. Automatic tympanometry in clinical practice. Audiology, 1974; 13: 126-39.

16. Lilly DJ, Margolis RH. Wideband acoustic immittance measurements of the middle ear: introduction and some historical antecedents. Ear Hear, 2013 Jul; 34 Suppl 1: 4S-8S. 
17. Rosowski JJ, Wilber LA. Acoustic immittance, absorbance, and reflectance in the human ear canal. Semin Hear, $2015 \mathrm{Feb}$; 36(1): $11-28$.

18. Śliwa L, Kochanek K. Nowe metody audiometrii impedancyjnej. Część II. Szerokopasmowa tympanometria reflektancyjna [New methods in acoustic immittance measurements. Part II. Wideband reflectance tympanometry]. Now Audiofonol, 2016; 5(4): $11-23$.
19. Sun XM. Wideband acoustic immittance: normative study and test-retest reliability of tympanometric measurements in adults. J Speech Lang Hear Res, 2016 Aug; 59(4): 819-34. 